\title{
Modulation of Plasma Membrane Composition and Microdomain Organization Impairs Heat Shock Protein Expression in B16-F10 Mouse Melanoma Cells
}

\author{
Tim Crul ${ }^{1, *,+}$, Balint Csoboz ${ }^{1,2,+}$, Imre Gombos ${ }^{1}$, Annamaria Marton ${ }^{1}$, Maria Peter ${ }^{1}$, \\ Gabor Balogh ${ }^{1}$, Csaba Vizler ${ }^{1}$, Lajos Szente ${ }^{3}$ and Laszlo Vigh ${ }^{1}$ \\ 1 Institute of Biochemistry, Biological Research Centre, Szeged 6726, Hungary; bcsoboz@gmail.com (B.C.); \\ gombos.imre@brc.hu (I.G.); marton.annamaria@brc.hu (A.M.); peter.maria@brc.hu (M.P.); \\ balogh.gabor@brc.hu (G.B.); vizler.csaba@brc.hu (C.V.); vigh.laszlo@brc.hu (L.V.) \\ 2 Institute of Medial Biology, University of Tromsø, Tromsø 9037, Norway \\ 3 Cyclolab Cyclodextrin R\&D Laboratory Ltd., 1097 Budapest, Hungary; szente@cyclolab.hu \\ * Correspondence: crul.tim@gmail.com; Tel.: +36-62-599-652 \\ + These authors contribute equally to this work.
}

Received: 5 March 2020; Accepted: 6 April 2020; Published: 12 April 2020

\begin{abstract}
The heat shock response (HSR) regulates induction of stress/heat shock proteins (HSPs) to preserve proteostasis during cellular stress. Earlier, our group established that the plasma membrane (PM) acts as a sensor and regulator of HSR through changes in its microdomain organization. PM microdomains such as lipid rafts, dynamic nanoscale assemblies enriched in cholesterol and sphingomyelin, and caveolae, cholesterol-rich PM invaginations, constitute clustering platforms for proteins functional in signaling cascades. Here, we aimed to compare the effect of cyclodextrin (M $\beta C D$ )- and nystatin-induced cholesterol modulations on stress-activated expression of the representative HSPs, HSP70, and HSP25 in mouse B16-F10 melanoma cells. Depletion of cholesterol levels with M $\beta C D$ impaired the heat-inducibility of both HSP70 and HSP25. Sequestration of cholesterol with nystatin impaired the heat-inducibility of HSP25 but not of HSP70. Imaging fluorescent correlation spectroscopy marked a modulated lateral diffusion constant of fluorescently labelled cholesterol in PM during cholesterol deprived conditions. Lipidomics analysis upon $\mathrm{M} \beta \mathrm{CD}$ treatment revealed, next to cholesterol reductions, decreased lysophosphatidylcholine and phosphatidic acid levels. These data not only highlight the involvement of PM integrity in HSR but also suggest that altered dynamics of specific cholesterol pools could represent a mechanism to fine tune HSP expression.
\end{abstract}

Keywords: plasma membrane; lipid raft; caveolae; HSP70; HSP25; cyclodextrin; nystatin

\section{Introduction}

When exposed to stress, cells induce the heat shock response (HSR), a multi-level signaling network characterized by the accumulation of a conserved set of so-called stress/heat shock proteins (HSPs) [1]. Being chaperoning proteins, HSPs recognize and prevent non-native protein conformations from forming deleterious protein aggregates during stress and, once the stressful event passed, assist in refolding or proteasomal degradation, depending on the extent of harmful exposure [2]. Based on structural similarities, HSPs are classified in several groups, including HSPA (HSP70), HSPB (small HSPs), HSPC (HSP90), HSPH (HSP110), HSPD/E (HSP60/HSP10), DnaJB (HSP40), and CCT (TRiC) [3]. Tight regulatory control of HSP expression is exerted by heat shock factor-1 (HSF1) which, under physiological conditions, mainly resides in the cytosol as an inactive monomer in complex with multiple HSPs. Stress-induced titration of HSPs from HSF1 allows it to quickly adopt 
a trimeric conformation, which is able to move into the nucleus while being modulated by multiple posttranslational modifications [4].

Based on this original model, HSP induction was primarily thought to be activated by protein denaturation and aggregation. However, it is now recognized that cells sense heat stress and activate the HSP expression machinery in multiple ways. For example, exposure to elevated temperatures fluidizes the plasma membrane and alters its physical properties and microdomain organization [5]. This activates fluidity-associated feed-back mechanisms controlling stress-responsive genes including HSPs [6]. Moreover, by acting as membrane-stabilizing factors [7], temporary association of certain HSPs with the plasma membrane [8] reduces its fluidity level [7], elevates bilayer stability [9], and thus restores membrane functionality during heat stress. Intriguingly, chemically induced PM fluidization and lipid raft reorganization with benzyl alcohol to levels similar as what is generally observed under heat stress caused a downshift of the HSR threshold resulting in induction of selected stress proteins at physiological temperatures in K562 and B16-F10 cells [10,11]. Of note, although benzyl alcohol and the close analogue phenethyl alcohol equally fluidized the PM, the latter did not reorganize the microdomains and subsequent HSP induction was absent, suggesting that a distinct reorganization of these microdomains is involved in the generation and transmission of stress signals to downstream HSP activation [10,12].

Different classes of PM microdomains have been recognized. Lipid rafts are PM microdomains enriched in cholesterol and sphingolipids which play an important role in the initiation of many signaling pathways. The fast, dynamic modulation of their structure results in an ever-changing content of both lipids and proteins which are essential for signal perception and transduction [13]. Caveolae are cholesterol-rich PM invaginations which cluster multiple proteins involved in signal transduction. Caveolae formation is regulated by the integral membrane protein caveolin- 1 which is necessary for and governs the major functions attributed to caveolae through interaction with caveolae-localized proteins. Upon stimulation, caveolae pinch off from the PM and translocate to the cytoplasm where they act as intracellular regulators of signaling cascades [14].

How changes in plasma membrane physical properties during physiological stress are transmitted intracellularly is not completely understood. A redistribution of cholesterol rich lipid rafts in parallel with an increased packing density of PM lipids correlated with enhanced HSP expression levels following heat exposure [15]. Since the structure of those lipid rafts strongly depends on lipid-phase behavior, thermally-controlled changes in PM fluidity modify the lateral segregation behavior of the embedded domains further suggesting their involvement in heat sensing and initiation of HSR $[10,16]$. In addition, heat-induced translocation of caveolin from the caveolae to the perinucleus has been reported indicating the involvement of caveolae in heat stress sensing [17]. Although not exactly understood, cytosolic release of caveolae-contained proteins, including caveolin-1, could thus link the PM to downstream pathways through direct interaction with specific targets [14].

As cholesterol is critical for the formation and configuration of lipid rafts and caveolae, targeted modulations of PM cholesterol levels or mobility is a widely used tool to disrupt the dynamic character of those microdomains and to study their involvement in cellular physiology. Methyl- $\beta$-cyclodextrin (M $\beta C D$ ) — a cyclic polysaccharide with high affinity for cholesterol-is one of the most commonly used tools to extract cholesterol from cellular membranes [18]. Nystatin-a polyene sterol-binding antimycotic-has current therapeutic applications and operates through a bi-phasic concentration-depended mode of action in fungal ergosterol-containing membranes. At low concentrations, sterol sequestration (immobilization) is observed perturbing the lipid packing characteristics of the membrane and reducing the ability of cholesterol to interact with and exert its effects on other membrane components. With increasing nystatin concentrations, additional nystatin-oligomerization-induced pore formation is generally observed. In mammalian cholesterol-containing membranes, sterol sequestration was equally observed; however, even at higher concentrations, pore formation was absent [19]. 
In the current study, we aimed to compare the effect of $M \beta C D$ - and nystatin-induced cholesterol modulations on heat-induced activation of HSP70 and HSP25-both known to be induced upon heat-in mouse B16-F10 melanoma cells. Next, we analyzed the effect of M $\beta C D$-induced cholesterol depletion on acquired thermotolerance, an adapted survival against extreme heat. With image-based fluorescence correlation spectroscopy, we analyzed the lateral diffusion constant of fluorescently labeled cholesterol in PM during M $\beta C D$ and nystatin treatment. Finally, as M $\beta C D$ actively extracts cholesterol out of PM, pushing the cells towards a new equilibrium, we performed in-depth lipidomics to follow the immediate effect of cholesterol deprivation on the whole cell lipidome.

\section{Materials and Methods}

\subsection{Cyclodextrin and Nystatin}

For each experiment, solutions of $\mathrm{M} \beta \mathrm{CD}$ (CylcoLabs, Budapest, Hungary; $10 \mathrm{mM}$ in serum-free RPMI medium) and nystastin (Sigma-Aldrich, Budapest, Hungary; $50 \mathrm{mg} / \mathrm{mL}$ in dimethyl sulfoxide (DMSO)) were freshly prepared. The $\mathrm{M} \beta \mathrm{CD}$ used was a statistically methylated beta-cyclodextrin with an average degree of methylation of 1.8 methyl groups per glucopyranose units (altogether 12.6 methyl groups per cyclodextrin ring).

\subsection{Cell Culture}

Mouse B16-F10 (ATCC CRL-6475) melanoma cells were grown in RPMI medium supplemented with $10 \%$ fetal calf serum, $4 \mathrm{mM}$ L-glutamine, and streptomycin/penicillin at $37^{\circ} \mathrm{C}$ in humidified incubator with $5 \% \mathrm{CO}_{2}$.

\subsection{Analysis of HSP70 and HSP25 Expression Levels}

Cells were either exposed to $10 \mathrm{mM} \mathrm{M} \beta C D$ for $10 \mathrm{~min}$ [18] or to $50 \mu \mathrm{g} / \mathrm{mL}$ nystatin for $1 \mathrm{~h}$ [20] at $37^{\circ} \mathrm{C}$ followed by heat stress for the indicated time at $42{ }^{\circ} \mathrm{C}$ in serum-supplemented RPMI medium and $3 \mathrm{~h}$ recovery at $37{ }^{\circ} \mathrm{C}$. Cells were lysed in RIPA buffer and HSP70 (ADI-SPA-810, Enzo Life Sciences, Farmingdale, NY, USA), HSP25 (ADI-SPA-801, Enzo Life Sciences), and GAPDH (G9545, Sigma-Aldrich) protein levels were analyzed through western blotting with the indicated antibodies. Signals were visualized by the use of HRP-conjugated secondary antibodies.

\subsection{Analysis of HSF1 Expression/Posttranslational Modification Levels}

Cells were either exposed to $10 \mathrm{mM} \mathrm{M} \beta C D$ for $10 \mathrm{~min}$ [18] or to $50 \mu \mathrm{g} / \mathrm{mL}$ nystatin for $1 \mathrm{~h}$ [20] at $37{ }^{\circ} \mathrm{C}$ followed by heat stress for the indicated time at $42{ }^{\circ} \mathrm{C}$ in serum-supplemented RPMI medium. Immediately after heat stress, cells were lysed in RIPA buffer and HSF1 (ADI-SPA-901, Enzo Life Sciences; RT-405, Thermo-Scientific, Waltham, MA, USA) and GAPDH (G9545, Sigma-Aldrich) were analyzed through western blotting with the indicated antibodies. Signals were visualized by the use of HRP-conjugated secondary antibodies.

\subsection{Analysis of Cholesterol Levels}

B16-F10 cells were exposed for $10 \mathrm{~min}$ to $10 \mathrm{mM} \mathrm{M} \beta \mathrm{CD}$ at $37^{\circ} \mathrm{C}$ followed by 30,60 , or 90 min heat stress at $42{ }^{\circ} \mathrm{C}$ in serum-supplemented RPMI medium. Immediately after stress, cholesterol levels were measured with the Amplex-red cholesterol assay kit according to the supplier's guidelines (Thermo Scientific).

\subsection{Stress Survival Experiments}

For acquired thermotolerance (ATT) measurements, B16-F10 cells were exposed to $10 \mathrm{mM} \mathrm{M} \beta \mathrm{CD}$ for $10 \mathrm{~min}$ at $37^{\circ} \mathrm{C}$ followed by 30,60 , or $90 \mathrm{~min}$ heat stress at $42^{\circ} \mathrm{C}$ in serum-supplemented RPMI medium. After $16-18 \mathrm{~h}$ recovery at $37^{\circ} \mathrm{C}$, all cells were exposed for $30 \mathrm{~min}$ to $45^{\circ} \mathrm{C}$. To estimate the fraction of surviving cells, resazurin, a fluorescent indicator of cellular metabolism, was added to 
the medium and cells were further incubated at $37^{\circ} \mathrm{C}$. At regular time points, the resulting change in fluorescence of growth medium was monitored at $565 \mathrm{~nm}$ excitation wavelength and $580 \mathrm{~nm}$ emission wavelength.

To test if a limited cholesterol resupply after $\mathrm{M} \beta \mathrm{CD}$ treatment during heat stress exposure should have an effect on the survival of M $\beta C D$-pretreated cells, B16-F10 cells were incubated for 10 min with $10 \mathrm{mM} \mathrm{M} \beta \mathrm{CD}$ at $37^{\circ} \mathrm{C}$ followed by 60 or 90 min heat shock at $42{ }^{\circ} \mathrm{C}$ in serum-supplemented RPMI- or serum-free RPMI medium. After pre-exposure heat stress, serum-free medium was exchanged for complete medium and cells were allowed to recover for $16-18 \mathrm{~h}$ at $37^{\circ} \mathrm{C}$. Then, cells were exposed for $30 \mathrm{~min}$ at $45^{\circ} \mathrm{C}$ and the following day, the fraction of surviving cells was estimated with resazurin as described above.

\subsection{Image-Based Fluorescence Correlation Spectroscopy (ImFCS)}

Cells were seeded into glass bottom dishes (MatTek Corporation, Ashland, MA, USA) two days before experiment. Measurements were performed in culturing media without phenol red at room temperature after labeling cells with $100 \mathrm{nM}$ Abberior Star 488 PEG cholesterol (ASP-Chol; Abberior, Göttingen, Germany) for $5 \mathrm{~min}$ and the subsequent washing steps. Objective type Total Internal Reflection illumination was used for achieving the thinnest excited sample volume with a high numerical aperture objective (alpha Plan-FLUAR 100; Zeiss, Oberkochen, Germany). Excitation wavelength $488 \mathrm{~nm}$ from a Spectra-Physics Stabile 2018 (Spectra-Physics; Santa Clara, CA, USA) laser as light source was introduced to the microscope (Zeiss Axiovert 200) by two tilting mirrors. The laser beam was focused on the back focal plane of the objective after a $488 \mathrm{~nm}$ cleanup filter and aZT488/647/780rpc-UF1 dichroic mirror (Chroma Technology GmbH, Olching, Germany). Sample signal was collected by the objective and filtered by a 535/70 emission filter (Chroma). For acquisition, we used a ProEM512 EMCCD camera (Princeton Instruments, Trenton, NJ, USA) with 3 milliseconds effective exposure time and $20 \times 40$ pixel acquisition area per measurement (pixel size $0.16 \mu \mathrm{m}$ ). The image-based fluorescence correlation spectroscopy (ImFCS) plugin (http://www.dbs.nus.edu.sg/lab/BFL/imfcs_image_j_plugin.html) for ImageJ software was used for data evaluation. The autocorrelation functions (ACFs) for every pixels were calculated using a multi-tau correlation scheme [21]. An exponential of polynomial bleach correction was used to correct data before fitting. For obtaining the diffusion coefficient (D) for all pixels, ACFs were fitted as described earlier [22]. The decreased number of reporter molecules caused by cholesterol depletion does not affect the calculated $\mathrm{D}$ since this evaluated parameter is independent in a broad range of molecule number [23].

\subsection{Lipidomics}

B16-F10 cells were exposed to $10 \mathrm{mMM} \beta \mathrm{CD}$ for 2,5 , and $10 \mathrm{~min}$ at $37^{\circ} \mathrm{C}$ and immediately thereafter collected. The pellets were shaken in $1 \mathrm{~mL}$ methanol containing $0.001 \%$ butylated hydroxytoluene as an antioxidant for $10 \mathrm{~min}$ and centrifuged at $10,000 \times g$ for $5 \mathrm{~min}$. The supernatant was transferred into a new reaction tube and stored at $-20^{\circ} \mathrm{C}$ [24]. All experiments were done in two biological repeats, each containing three technical repeats. Mass spectrometry analyses were done as described earlier [25]. PLS-DA was performed with the Metaboanalyst suite 4.0 [26].

\subsection{Statistics}

Band intensities of HSP70 and HSP25 measured upon M $\beta C D$ followed by heat were analyzed with 2-way ANOVA followed by Sidak's multiple comparisons test. Band intensities of HSP70 and HSP25 upon nystatin followed by heat were analyzed with one-way ANOVA followed by Tukey's multiple comparisons test. Band intensities of HSF1 upon M $\beta C D$ or nystatin followed by heat were analyzed with one-way ANOVA followed by Tukey's multiple comparisons test. Data of ATT experiments, effect of serum-supplemented versus serum-free medium experiments, and cholesterol replenishment experiments was analyzed with ANOVA followed by Tukey's multiple comparisons test. 


\section{Results}

3.1. Plasma Membrane Modulations with Methyl- $\beta$-Cyclodextrin (M $\beta C D)$ and Nystatin Impair the Heat-Induced Stress Response

Considering the involvement of cholesterol-rich PM microdomains in HSR, we wanted to compare the effect of $M \beta C D$ - and nystatin-induced cholesterol modulations on the stress-induced activation of selected HSPs. We decided to focus on stress-induced activation of HSP70 (HSPA1A) and the small HSP HSP25 (HSPB1), representative HSPs known to be highly upregulated upon heat exposure.

First, B16-F10 cells were incubated for $10 \mathrm{~min}$ with $10 \mathrm{mM} \mathrm{M \beta CD}$ at $37{ }^{\circ} \mathrm{C}$ followed by 30,60 , or $90 \mathrm{~min}$ heat stress at $42{ }^{\circ} \mathrm{C}$ and $3 \mathrm{~h}$ recovery at $37^{\circ} \mathrm{C}$. Compared to untreated cells, $\mathrm{M} \beta \mathrm{CD}$ treatment resulted in lower heat-induced HSP70 and HSP25 levels in a time-dependent manner (Figure 1A). Considering the impaired heat-induced stress response upon $\mathrm{M} \beta \mathrm{CD}$ exposure, we analyzed HSF1 post-translational modification (PTM) levels. Upon stress, HSF1 is modulated by multiple posttranslational modifications. Currently, 30 amino acids have been identified in the HSF1 sequence which are susceptible to phosphorylation, acetylation, summoylation, and O-glycosylation [4]. As PTMs add to the molecular weight of the targeted protein, this might result in a pronounced band shift which can be visualized by western blotting. B16-F10 cells exposed for 2,5 or $10 \mathrm{~min}$ to $10 \mathrm{mM}$ $\mathrm{M} \beta \mathrm{CD}$ at $37^{\circ} \mathrm{C}$ followed by $1 \mathrm{~h}$ heat shock at $42^{\circ} \mathrm{C}$ had a reduced HSF1 band shift in a time-dependent manner (Figure 1B), suggesting a modulated HSF1 posttranslational profile.

Next, B16-F10 cells were exposed for $1 \mathrm{~h}$ to $50 \mu \mathrm{g} / \mathrm{mL}$ nystatin at $37^{\circ} \mathrm{C}$ followed by $1 \mathrm{~h}$ heat stress at $42{ }^{\circ} \mathrm{C}$ and $3 \mathrm{~h}$ recovery at $37^{\circ} \mathrm{C}$. Compared to untreated cells, nystatin resulted in reduced heat-induced HSP25 levels but had no effect on HSP70 levels (Figure 1C). We then analyzed for nystatin-induced changes in HSF1 expression/post-translational modification levels and exposed B16-F10 cells for $1 \mathrm{~h}$ to $50 \mu \mathrm{g} / \mathrm{mL}$ nystatin at $37^{\circ} \mathrm{C}$ followed by heat stress for $1 \mathrm{~h}$ at $42{ }^{\circ} \mathrm{C}$. Immediately after heat stress, nystatin exposure resulted in a less pronounced HSF1 signal compared to the heat stress control (Figure 1D).

A
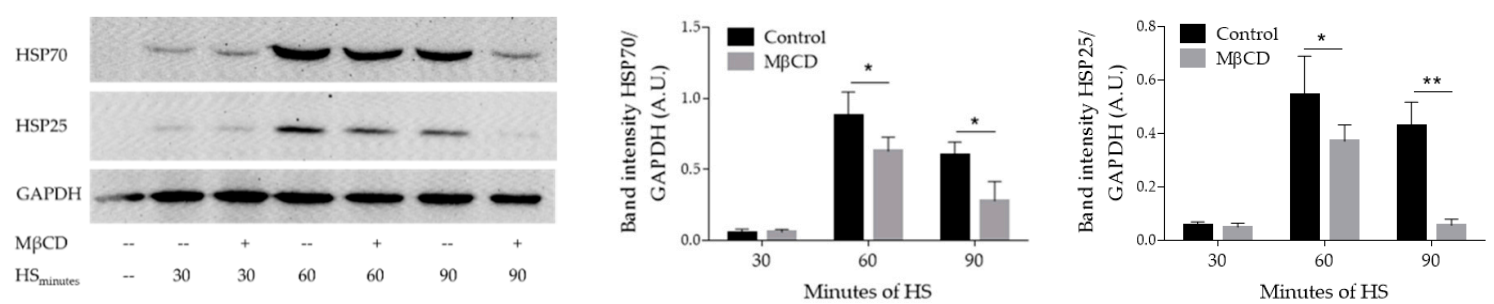

B
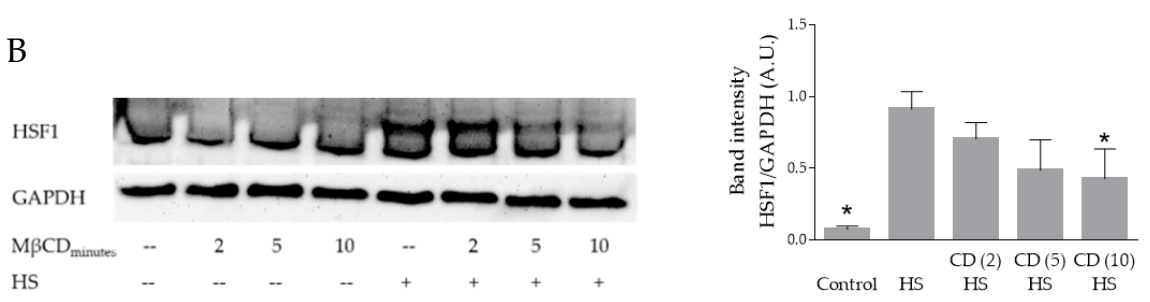

Figure 1. Cont. 

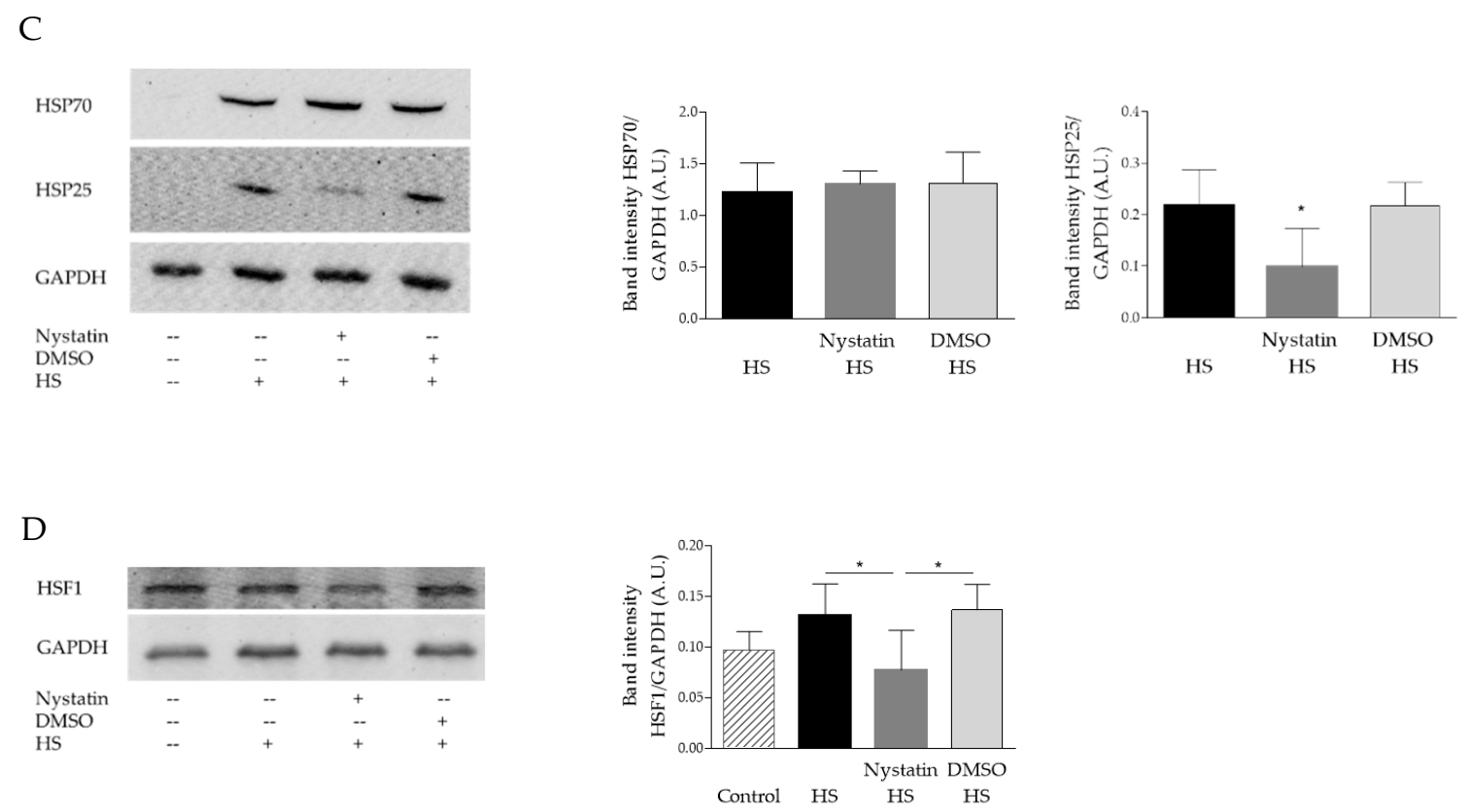

Figure 1. Effect of PM modulation on heat-induced heat shock response. (A) B16-F10 cells were incubated for $10 \mathrm{~min}$ with $10 \mathrm{mM}$ Methyl- $\beta$-cyclodextrin $(\mathrm{M} \beta \mathrm{CD})$ at $37^{\circ} \mathrm{C}$ followed by 30,60 , or $90 \mathrm{~min}$ of heat stress at $42{ }^{\circ} \mathrm{C}$ and $3 \mathrm{~h}$ recovery at $37^{\circ} \mathrm{C}$; (B) B16-F10 cells were incubated for 2, 5, or $10 \mathrm{~min}$ with $10 \mathrm{mM} \mathrm{M} \beta \mathrm{CD}$ at $37{ }^{\circ} \mathrm{C}$ followed by $1 \mathrm{~h}$ heat shock at $42{ }^{\circ} \mathrm{C}$; (C) B16-F10 cells were exposed for $1 \mathrm{~h}$ to $50 \mu \mathrm{g} / \mathrm{mL}$ nystatin at $37^{\circ} \mathrm{C}$ followed by $1 \mathrm{~h}$ heat stress at $42^{\circ} \mathrm{C}$ and $3 \mathrm{~h}$ recovery at $37^{\circ} \mathrm{C}$; (D) B16-F10 cells were exposed for $1 \mathrm{~h}$ to $50 \mu \mathrm{g} / \mathrm{mL}$ nystatin at $37^{\circ} \mathrm{C}$ followed by heat stress for $1 \mathrm{~h}$ at $42{ }^{\circ} \mathrm{C}$. Bar graphs show quantified band intensities normalized to GAPDH $(n=3),{ }^{*} p<0.05 ;{ }^{* *} p<0.01$. $\mathrm{CD}(\mathrm{X})$ : cells exposed for 2,5 , or $10 \mathrm{~min}$ to $\mathrm{M} \beta \mathrm{CD}$. DMSO was treated as a vehicle control for nystatin. A.U.: arbitrary units, HS: heat shock.

\subsection{Plasma Membrane Modulation with M $\beta C D$ Alters Acquired Thermotolerance of B16-F10 Cells}

Acquired thermotolerance (ATT) is an adapted ability of cells to survive otherwise lethal heat in response to an earlier pre-exposure to non-lethal stress. Considering the observed effects of targeted PM modulation by M $\beta C D$ on heat-induced HSP70 and HSP25 expression, we next wanted to analyze its effect on ATT.

First, B16-F10 cells were exposed for $10 \mathrm{~min}$ to $10 \mathrm{mM} \mathrm{M} \beta \mathrm{CD}$ at $37^{\circ} \mathrm{C}$ followed by 30,60 , or $90 \mathrm{~min}$ of heat stress at $42{ }^{\circ} \mathrm{C}$ in serum-supplemented RPMI medium (pre-exposure). Then, after 16-18 $\mathrm{h}$ recovery at $37^{\circ} \mathrm{C}$, cells were re-exposed to heat stress for $30 \mathrm{~min}$ at $45^{\circ} \mathrm{C}$. The following day, the fraction of surviving cells was estimated with resazurin. Upon $30 \mathrm{~min}$ of pre-exposure heat, $\mathrm{M} \beta \mathrm{CD}$ resulted in reduced ATT compared to non-treated heat-shocked cells. However, from $60 \mathrm{~min}$ pre-exposure heat onwards, a similar ATT was observed in $\mathrm{M} \beta \mathrm{CD}$-treated cells compared to the time-matched control cells (Figure 2A).

Following this observation and considering the very high affinity of $\mathrm{M} \beta \mathrm{CD}$ for cholesterol, we hypothesized that while being exposed to heat stress, plasma membrane cholesterol levels might re-equilibrate allowing for restored heat sensing and resulting stress response as observed from $60 \mathrm{~min}$ pre-exposure heat onwards. Thus, a limited cholesterol resupply after M $\beta C D$ treatment during heat stress exposure should have an effect on the survival of $M \beta C D$-pretreated cells. To test this possibility, B16-F10 cells were incubated for 10 min with $10 \mathrm{mM} \mathrm{M \beta CD}$ at $37^{\circ} \mathrm{C}$ followed by 60 or 90 min heat shock at $42{ }^{\circ} \mathrm{C}$ in serum-supplemented RPMI- or serum-free RPMI medium. After pre-exposure heat stress, serum-free medium was exchanged for complete medium and cells were allowed to recover for $16-18 \mathrm{~h}$ at $37^{\circ} \mathrm{C}$. Then, cells were exposed for $30 \mathrm{~min}$ at $45^{\circ} \mathrm{C}$ and the following day, the fraction of surviving cells was estimated with resazurin. As expected, pre-exposure heat in serum-supplemented RPMI medium for $60 \mathrm{~min}$ or longer resulted in similar ATT in M $\beta C D$-treated cells compared to 
time-matched pre-exposure heat control cells (Figure 2B). However, pre-exposure heat in serum-free RPMI medium for 60 min almost reached statistical significantly lower ATT in M $\beta C D$-treated cells compared to time-matched pre-exposure heat control cells $(p=0.06)$, whereas pre-exposure heat in serum-free RPMI medium for 90 min resulted in significantly lower ATT in M $\beta C D$-treated cells compared to time-matched pre-exposure heat control cells $(p<0.05)$ (Figure 2B). Considering the high affinity of $\mathrm{M} \beta \mathrm{CD}$ towards cholesterol, this suggested that most probably cholesterol supply from the serum-supplemented medium influences the restoration of the $\mathrm{M} \beta \mathrm{CD}$-impaired stress response.

A

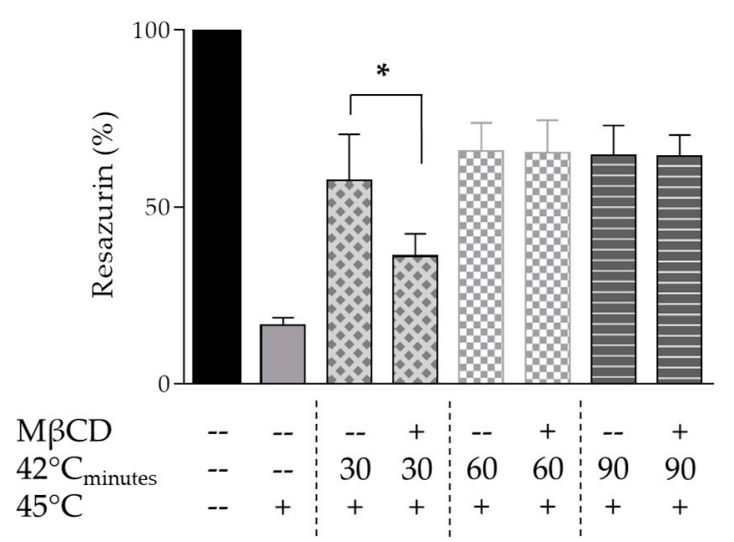

B

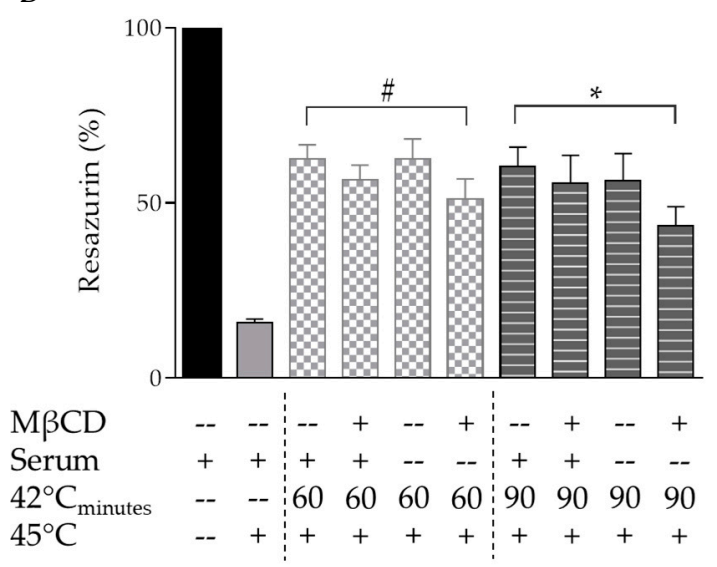

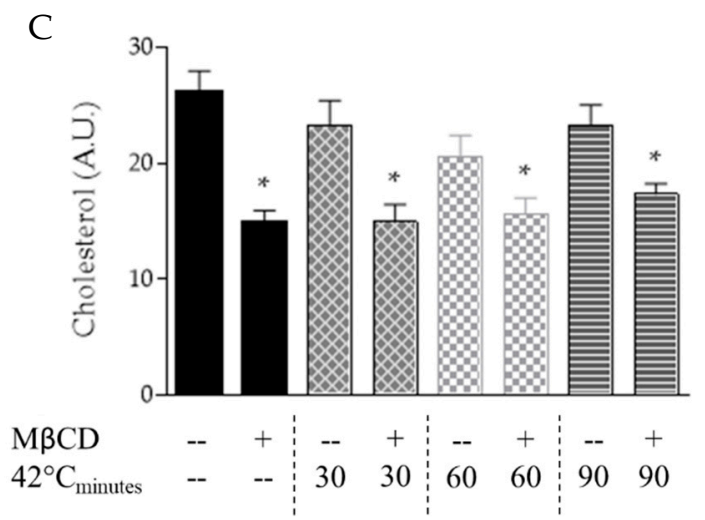

Figure 2. Effect of $\mathrm{M} \beta \mathrm{CD}$-induced PM modulation on development of acquired thermotolerance (ATT) in B16-F10 cells. (A) B16-F10 cells were exposed for $10 \mathrm{~min}$ to $10 \mathrm{mM} \mathrm{M} \beta \mathrm{CD}$ at $37^{\circ} \mathrm{C}$ followed by 30 , 60 , or $90 \mathrm{~min}$ of heat stress at $42^{\circ} \mathrm{C}$ (pre-exposure). Then, after $16-18 \mathrm{~h}$ recovery at $37^{\circ} \mathrm{C}$, cells were re-exposed to heat stress for $30 \mathrm{~min}$ at $45^{\circ} \mathrm{C}$. The following day, the fraction of surviving cells was estimated with resazurin $\left(n=4,{ }^{*} p<0.05\right)$; (B) B16-F10 cells were incubated for $10 \mathrm{~min}$ with $10 \mathrm{mM}$ $\mathrm{M} \beta \mathrm{CD}$ at $37^{\circ} \mathrm{C}$ followed by 60 or $90 \mathrm{~min}$ heat shock at $42{ }^{\circ} \mathrm{C}$ in serum-supplemented- or serum-free RPMI medium (limiting cholesterol supply). After pre-exposure heat stress, serum-free medium was exchanged for complete medium and cells were allowed to recover for $16-18 \mathrm{~h}$ at $37^{\circ} \mathrm{C}$. Then, cells were exposed for $30 \mathrm{~min}$ at $45^{\circ} \mathrm{C}$ and the following day, the fraction of surviving cells was estimated with resazurin $\left(n=3,{ }^{*} p=0.06,{ }^{*} p<0.05\right)$; (C) B16-F10 cells were exposed for $10 \mathrm{~min}$ to $10 \mathrm{mM} \mathrm{M} \beta C D$ at $37^{\circ} \mathrm{C}$ followed by 30,60 , or $90 \mathrm{~min}$ heat shock at $42{ }^{\circ} \mathrm{C}$ and cholesterol levels were measured immediately after heat stress $\left(n=6,{ }^{*} p<0.05\right.$ compared to $37^{\circ} \mathrm{C}$ control,). A.U.: arbitrary units.

Thus, we analyzed cholesterol levels during pre-exposure heat in M $\beta C D$-treated cells. B16-F10 cells were exposed for $10 \mathrm{~min}$ to $10 \mathrm{mM} \mathrm{M} \beta \mathrm{CD}$ at $37^{\circ} \mathrm{C}$ followed by 30,60 , or 90 min heat shock at $42^{\circ} \mathrm{C}$ and cholesterol levels were measured immediately after heat stress. At every time point measured, cholesterol levels of $\mathrm{M} \beta C D$-treated cells did not recover to baseline and were always significantly lower compared to those of untreated non-heat-shocked control cells (Figure 2C). This would suggest 
that apart from cholesterol, hitherto unknown factors present in serum might influence the restoration of the $\mathrm{M} \beta C \mathrm{CD}$-impaired stress response.

Treatment of B16-F10 cells with nystatin resulted in reduced heat-induced HSP25 expression level (Figure 1C). Considering the published involvement of HSP25 on development of thermotolerance $[27,28]$, we did not perform nystatin-related ATT assays as a similar effect as to that observed with $M \beta C D$ was anticipated.

\subsection{Exposure to $M \beta C D$ Alters the Lateral Diffusion of Cholesterol in the Plasma Membrane}

To analyze the immediate effect of PM modulation on the lateral diffusion of cholesterol, a fluorescent analogue (ASP-Chol) was used which reports only from the outer leaflet of PM since the flip/flop of this reporter is prevented due to the polyethylene linker. First, imaging fluorescence correlation spectroscopy (ImFCS) measurements were performed on labeled cells before and during $\mathrm{M} \beta C D$ exposure. The significant decrease of lateral diffusion speed observed within the first minutes of $M \beta C D$ exposure was followed by a slower decay (Figure 3). Next, ImFCS measurements were performed on labeled cells before and after $1 \mathrm{~h}$ of nystatin exposure. However, exposure to nystatin did not result in any significant change of the diffusion constant (data not shown).

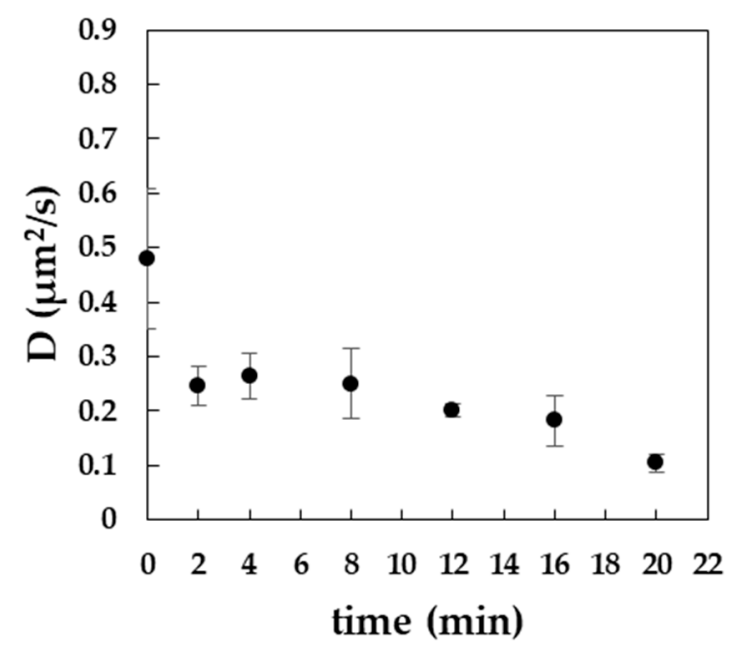

Figure 3. Diffusion constant of Abberior Star 488 PEG cholesterol probe (ASP-Chol) in the plasma membrane of B16-F10 cells upon exposure to $10 \mathrm{mM} \mathrm{M \beta CD}$ for the indicated time.

\subsection{Lipidomics Analysis Indicates an Immediate and Extensive MBCD-Induced Lipidome Remodeling}

As $\mathrm{M} \beta C D$ actively extracts cholesterol out of PM, we anticipated that it might push the cell towards a new PM compositional equilibrium. Thus, we decided to perform in-depth lipidomics to follow the immediate effect of $\mathrm{M} \beta \mathrm{CD}$-induced cholesterol deprivation on the whole cell lipidome.

B16-F10 cells were treated with $10 \mathrm{mM} \mathrm{M} \beta C D$ for 2, 5, and $10 \mathrm{~min}$ at $37^{\circ} \mathrm{C}$ and immediately thereafter the total cellular lipid content was isolated and analyzed with mass spectrometry. First, we confirmed the established affinity of $\mathrm{M} \beta \mathrm{CD}$ towards cholesterol in our dataset by reaching a reduction of up to $50 \%$ of cholesterol levels in $10 \mathrm{~min}$ (Figure $4 \mathrm{~A}$ ). Next, before proceeding with the statistical analysis, we removed the cholesterol values from our dataset. As such, we avoid that the large effect of $\mathrm{M} \beta C D$ on cholesterol might mask more subtle but potentially relevant changes of other lipid species. Interestingly, PLS-DA analysis [29] still indicated a good separation of the different time points (Figure 4B); cross-validation with 2 components revealed good predictability $(\mathrm{Q} 2=0.74)$ and high goodness of fit $(\mathrm{R} 2=0.93)$. Sphingomyelin, lysophosphatidylcholine, and phosphatidic acid species were identified among the 10 mostly altered features due to $M \beta C D$ exposure (Figure $4 C$ ). By analyzing the time-dependent changes in the levels of these lipid species, an immediate decrease of 
lysophosphatidylcholine species was visible (Figure 4D) whereas phosphatidic acid and sphingomyelin species displayed a more delayed onset of decrease (Figure 4E,F).

A

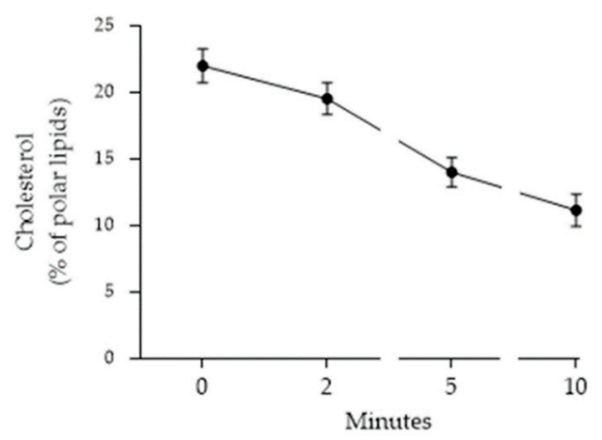

$\mathrm{C}$

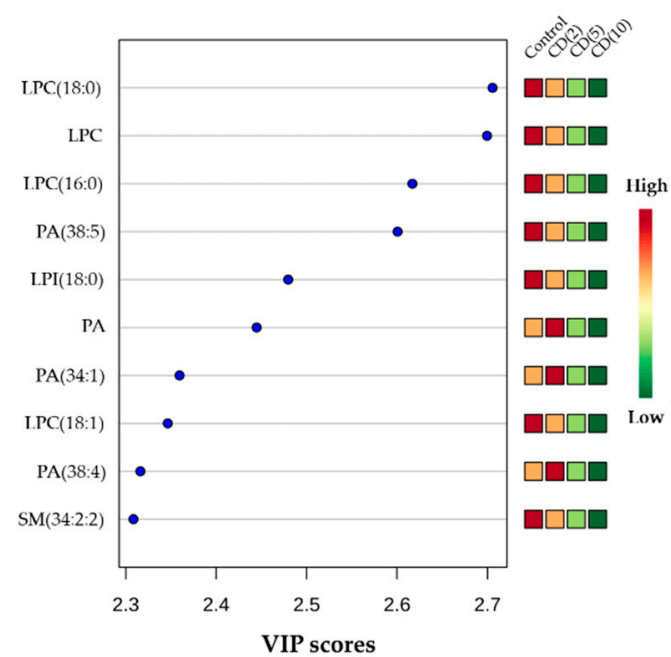

E

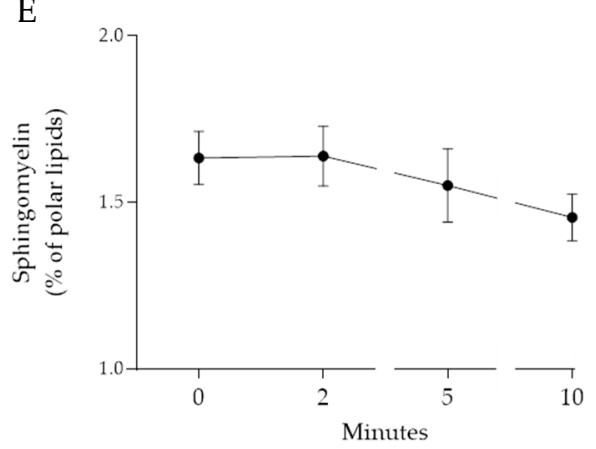

B

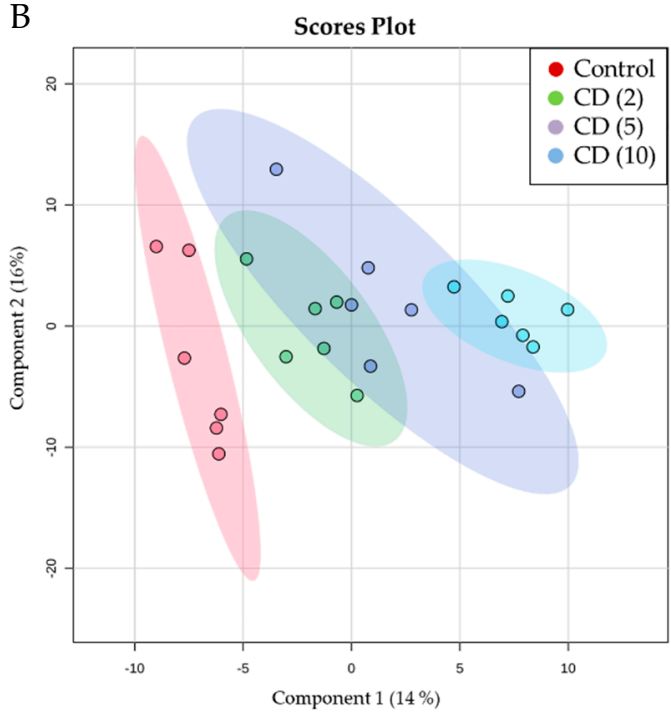

$\mathrm{D}$

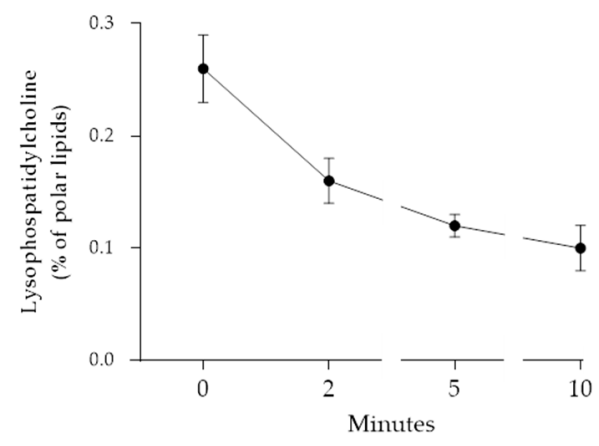

F

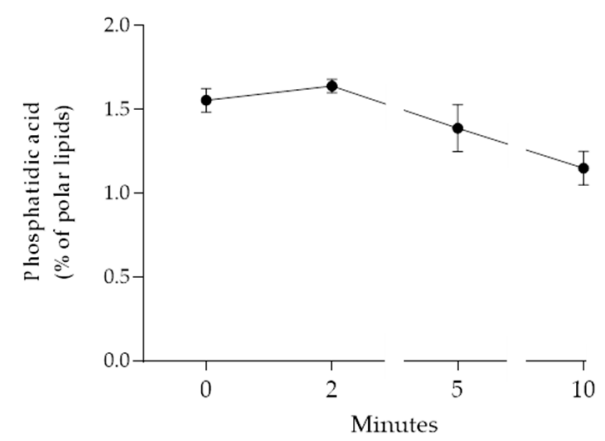

Figure 4. Effect of $\mathrm{M} \beta \mathrm{CD}$ on B16-F10 lipidome. (A) Time-dependent changes in the levels of cholesterol; (B) PLS-DA scores plot generated without cholesterol values; (C) Most important discriminative features due to $\mathrm{M} \beta C D$ treatment: lysophosphatidylcholine (LPC), phosphatidic acid (PA), lysophosphatidylinositol (LPI), sphingomyelin (SM); Time-dependent changes in the levels of lysophosphatidylcholine (D), sphingomyelin (E), and phosphatidic acid (F). CD (X): cells exposed for 2, 5 , or $10 \mathrm{~min}$ to $\mathrm{M} \beta C \mathrm{CD}$. 
In mammalian cholesterol-containing membranes, nystatin operates through sterol sequestration/immobilization without the formation of pores [19]. Therefore, in-depth nystatin-related lipidomics were not performed as similar cholesterol levels compared to control were anticipated excluding the need for the cells to reach a new PM compositional equilibrium.

\section{Discussion}

The involvement of cholesterol-rich PM microdomains such as lipid rafts and caveolae in HSR was previously suggested $[17,30]$. To further study the involvement of those microdomains in HSR, we compared the effect of $\mathrm{M} \beta \mathrm{CD}$ - and nystatin-induced modulations on stress-induced activation of the representative HSPs HSP70 and HSP25 in mouse B16-F10 melanoma cells.

Treatment with M $\beta C D$ resulted in diminished heat-induced HSP70 and HSP25 expression (Figure 1A), whereas treatment with nystatin diminished heat-induced HSP25 expression without affecting HSP70 induction (Figure 1C). These observations suggest that, under the conditions used, $\mathrm{M} \beta \mathrm{CD}$ and nystatin likely acted upon different cholesterol pools. Interestingly, a specific selectivity of $\mathrm{M} \beta C D$-induced cholesterol depletion towards lipid raft regions has been suggested, depending on exposure time (up to $10 \mathrm{~min}$ ) and/or concentration used [18]. Additionally, a specific disruption of caveolae by nystatin without modifying other PM microdomains was previously suggested by deep-etch freeze microscopy [20]. Consequently, based on our results and considering the published conditional selectivity of $\mathrm{M} \beta \mathrm{CD}$ and nystatin towards respectively lipid rafts and caveolae, it is tempting to speculate that selective heat-induced activation of lipid rafts or caveolae are likely to target specific HSP subpopulations. Consistent with our nystatin data is the intriguing observation that genetic disruption of caveolin-1—an essential component of functional caveolae-in mouse mammary tumor cells was shown to impair the expression of HSP25 but not HSP70 [31].

In line with the observed altered HSP profile compared to untreated heat shocked cells, we observed an altered stress-induced HSF1 PTM pattern upon PM modulation with $M \beta C D$ or nystatin (Figure 1B,D). Upon heat, HSF1 is targeted by multiple PM-originating signaling cascades which play a defining role in its activation [32]. Currently, we can only speculate which signaling cascade(s) might be affected. For example, both JNK [33] and p38 MAP kinases [34] were previously suggested to take part in membrane-associated HSP25 induction. Of note, cholesterol depletion inhibited JNK and p38 MAP kinase-associated signaling in different model systems $[35,36]$. Thus, it is tempting to speculate that M $\beta C D$ - or nystatin-induced PM modifications impair different signaling cascades towards HSF1 resulting in an altered PTM profile. Although the precise role of HSF1 PTMs is unknown [37] it is suggested to provide specificity towards its binding preferences to selected heat shock elements in the promotor region of a subset of hsp genes [38]. In addition, induction of HSP70 and HSP25 depends on the nuclear domain ND-10-associated proteins Daxx and PML [39]. Previously, interaction of Daxx and HSF1 during HSR was reported [40]. In fact, in mouse embryonic fibroblasts, release of Daxx from the nuclear domain correlated with HSP25 suppression whereas release of PML correlated with lower HSP70 levels. Considering that Daxx acts as a regulator of cholesterol synthesis through association with the androgen receptor [41], it is tempting to speculate that $\mathrm{M} \beta C D$-induced cholesterol depletion could titrate Daxx away from the HSF1 regulatory complex resulting in the observed impaired HSP25 induction upon heat.

Interestingly, $\mathrm{M} \beta \mathrm{CD}$ impaired acquired thermotolerance in B16-F10 when cells were pre-exposed to a short (30 $\mathrm{min}$ ) period of sublethal heat (Figure $2 \mathrm{~A})$. However, prolonged pre-exposure ( $>60 \mathrm{~min})$ to sublethal heat did not result in $\mathrm{M} \beta C D$-induced impaired acquired thermotolerance. Multiple scenarios might explain this observation. (a) M $\beta C D$-induced alterations in PM cholesterol levels and microdomain disruption are restored during prolonged pre-exposure to sublethal heat resulting in restored signaling cascades and HSP expression levels. The finding that even prolonged pre-exposure to sublethal heat in serum-free medium-limiting external cholesterol supply-impaired acquired thermotolerance, supports this assumption (Figure 2B). However, even when cells were pre-exposed for up to $90 \mathrm{~min}$ of sublethal heat in serum-supplemented medium, cellular cholesterol levels were 
not restored to levels comparable to those of untreated cells (Figure 2C). Additionally, prolonged pre-exposure for up to $90 \mathrm{~min}$ to sublethal heat did not result in restored HSP expression levels (Figure 1A). (b) As a potential feedback mechanism, prolonged pre-exposure to sublethal heat might activate alternative signaling and/or survival mechanisms resulting in restored survival. In fact, the mouse macrophage tumor cell line P388D1 displayed heat-induced thermotolerance in the absence of HSF1 transactivation capacity and subsequent HSP induction [42]. Additionally, CHO [25] and murine B-cell lymphoma $\mathrm{CH} 1$ [43] cells displayed heat-induced thermotolerance in the complete absence of HSP expression. As of now, we can only speculate about the potential nature of these alternative mechanisms. Currently, in-depth RNAseq experiments are ongoing in our lab to explore the specific underlying molecular mechanisms responsible for the observed restored ATT upon prolonged pre-exposure to sublethal heat.

Recently, by using advanced fluorescence imaging and spectroscopy approaches, a two-component diffusion model for cholesterol in the PM of live cells was proposed suggesting a heterogeneous diffusion in the cell membrane which is due to its nanoscale interactions and localization in the membrane [44]. In the current study, by using a fluorescently-labeled cholesterol analogue as a reporter for lateral cholesterol diffusion, we observed a quick decrease of the diffusion constant during $M \beta C D$ treatment (Figure 3). Although our fluorescent cholesterol probe might not completely reflect the native behavior of the endogenous cholesterol, this might suggest an altered composition and structure of the PM caused by the cholesterol depletion. Of note, one-hour nystatin exposure did not affect the lateral diffusion of the cholesterol probe. Currently, we can only speculate about the differences in the observed changes in lateral diffusion between $\mathrm{M} \beta \mathrm{CD}$ - or nystatin exposure and assume that they might be due to their respective mode of action (extraction vs. sequestration/immobilization).

Apart from cholesterol, we identified additional potentially relevant $\mathrm{M} \beta \mathrm{CD}$-induced changes in the lipidome of B16-F10 cells. In addition to previously reported $\mathrm{M} \beta \mathrm{CD}$-induced decreases in sphingomyelin levels [18], a gradual decrease in lysophosphatidylcholine (LPC) and phosphatidic acid (PA) species was observed (Figure 4D-F). Thus, our study indicates that M $\beta C D$ affects other lipid species as well suggesting that the effects of $\mathrm{M} \beta C D$ on cell physiology as described in the literature might go well beyond changes in cholesterol levels and in fact be of a much more complex nature. Precisely how these changes came about-active uptake by $\mathrm{M} \beta C D$, lipid metabolism, or passive leakage/active transport into the extracellular milieu-is currently not known.

Of note, based on in vitro studies, a chaperone-like function of LPC able to prevent thermally-induced protein denaturation was suggested, implying a potential function in preserving the conformation and function of PM-embedded signaling proteins during heat stress [45]. On the other hand, PA functions as a precursor for the generation of bioactive lipids such as diacylglycerol (DAG) [46]. Intriguingly, since perception of heat stress at the level of PM relies among others on DAG-mediated arachidonic acid generation which ultimately modulates HSF1 activity [32], these minor but relevant reduction in LPC and/or PA levels might also have a potential role in the observed impaired stress sensing. In fact, we earlier demonstrated the role of nutritional lipid supply to cell culture medium in stress-sensing through reorganization of cholesterol-rich microdomains [47]. Currently, we can only speculate about the potential underlying mechanisms of these changed lipid species levels in our findings which should be addressed in future studies. For example, the size and/or function of the specific lipid-associated HSP70 pools—as recently discussed by Balogi et al. [48]—could be affected by the observed $\mathrm{M} \beta \mathrm{CD}$-induced lipidome alterations and might be of importance when interpreting our current findings.

\section{Conclusions}

Our data demonstrated impaired heat-induced HSP expression levels upon targeted PM modulation in B16-F10 cells. These data not only highlight the involvement of PM integrity in HSR but also suggest that altered dynamics of specific cholesterol pools could represent a mechanism to fine tune HSP expression. Considering that cholesterol exchange between cells through direct 
cell-cell contacts has recently been shown [49], membrane-compound exchange through cell-to-cell communication could in fact represent an hitherto less recognized mechanism through which stress adaptation could spread throughout a larger cell population.

Author Contributions: Conceptualization, T.C. and B.C.; Formal analysis, T.C., B.C., I.G., A.M., M.P., G.B. and C.V.; Funding acquisition, T.C.; Investigation, T.C., B.C., I.G., A.M., M.P., G.B. and C.V.; Resources, L.S.; Supervision, L.V.; Writing-original draft, T.C. and B.C.; Writing-review \& editing, T.C. and B.C. All authors have read and agreed to the published version of the manuscript.

Funding: This research was funded by the Hungarian Scientific Research Fund (OTKA/NFKI), grant number 453 PD-109539 and from the GINOP-2.3.2-15-2016-00040.

Conflicts of Interest: The authors declare no conflict of interest.

\section{References}

1. Kültz, D. Molecular and evolutionary basis of the cellular stress response. Annu. Rev. Physiol. 2005, 67, 225-257. [CrossRef] [PubMed]

2. Lindquist, S. The Heat-Shock Response. Annu. Rev. Biochem. 1986, 55, 1151-1191. [CrossRef] [PubMed]

3. Kampinga, H.H.; Hageman, J.; Vos, M.J.; Kubota, H.; Tanguay, R.M.; Bruford, E.; Cheetham, M.E.; Chen, B.; Hightower, L.E. Guidelines for the nomenclature of the human heat shock proteins. Cell Stress Chaperones 2008, 14, 105-111. [CrossRef] [PubMed]

4. Anckar, J.; Sistonen, L. Regulation of H SF 1 Function in the Heat Stress Response: Implications in Aging and Disease. Annu. Rev. Biochem. 2011, 80, 1089-1115. [CrossRef]

5. Horváth, I.; Glatz, A.; Varvasovszki, V.; Török, Z.; Páli, T.; Balogh, G.; Kovács, E.; Nádasdi, L.; Benkö, S.; Joó, F.; et al. Membrane physical state controls the signaling mechanism of the heat shock response in Synechocystis PCC 6803: Identification of hsp17 as a "fluidity gene". Proc. Natl. Acad. Sci. USA 1998, 95, 3513-3518. [CrossRef]

6. Horvàth, I.; Multhoff, G.; Sonnleitner, A.; Vígh, L. Membrane-associated stress proteins: More than simply chaperones. Biochim. et Biophys. Acta (BBA)-Biomembr. 2008, 1778, 1653-1664. [CrossRef]

7. Török, Z.; Goloubinoff, P.; Horváth, I.; Tsvetkova, N.M.; Glatz, A.; Balogh, G.; Varvasovszki, V.; Los, D.A.; Vierling, E.; Crowe, J.H.; et al. Synechocystis HSP17 is an amphitropic protein that stabilizes heat-stressed membranes and binds denatured proteins for subsequent chaperone-mediated refolding. Proc. Natl. Acad. Sci. USA 2001, 98, 3098-3103. [CrossRef]

8. Balogi, Z.; Cheregi, O.; Giese, K.C.; Juhász, K.; Vierling, E.; Vass, I.; Vígh, L.; Horváth, I. A mutant small heat shock protein with increased thylakoid association provides an elevated resistance against UV-B damage in synechocystis 6803. J. Boil. Chem. 2008, 283, 22983-22991. [CrossRef]

9. Tsvetkova, N.M.; Horváth, I.; Török, Z.; Wolkers, W.F.; Balogi, Z.; Shigapova, N.; Crowe, L.M.; Tablin, F.; Vierling, E.; Crowe, J.H.; et al. Small heat-shock proteins regulate membrane lipid polymorphism. Proc. Natl. Acad. Sci. USA 2002, 99, 13504-13509. [CrossRef]

10. Nagy, E.; Balogi, Z.; Gombos, I.; Åkerfelt, M.; Björkbom, A.; Balogh, G.; Török, Z.; Maslyanko, A.; Fiszer-Kierzkowska, A.; Lisowska, K.M.; et al. Hyperfluidization-coupled membrane microdomain reorganization is linked to activation of the heat shock response in a murine melanoma cell line. Proc. Natl. Acad. Sci. USA 2007, 104, 7945-7950. [CrossRef]

11. Balogh, G.; Horvàth, I.; Nagy, E.; Hoyk, Z.; Benkő, S.; Bensaude, O.; Vígh, L. The hyperfluidization of mammalian cell membranes acts as a signal to initiate the heat shock protein response. FEBS J. 2005, 272, 6077-6086. [CrossRef] [PubMed]

12. Balogh, G.; Maulucci, G.; Gombos, I.; Horváth, I.; Török, Z.; Péter, M.; Fodor, E.; Pali, T.; Benkő, S.; Parasassi, T.; et al. Heat Stress Causes Spatially-Distinct Membrane Re-Modelling in K562 Leukemia Cells. PLoS ONE 2011, 6, e21182. [CrossRef] [PubMed]

13. Sezgin, E.; Levental, I.; Mayor, S.; Eggeling, C. The mystery of membrane organization: Composition, regulation and roles of lipid rafts. Nat. Rev. Mol. Cell Boil. 2017, 18, 361-374. [CrossRef] [PubMed]

14. Parton, R.G.; Tillu, V.; Collins, B.M. Caveolae. Curr. Boil. 2018, 28, R402-R405. [CrossRef]

15. Balogh, G.; Péter, M.; Glatz, A.; Gombos, I.; Török, Z.; Horvàth, I.; Harwood, J.L.; Vígh, L. Key role of lipids in heat stress management. FEBS Lett. 2013, 587, 1970-1980. [CrossRef] 
16. Csoboz, B.; Balogh, G.E.; Kúsz, E.; Gombos, I.; Péter, M.; Crul, T.; Gungor, B.; Haracska, L.; Bogdanovics, G.; Török, Z.; et al. Membrane fluidity matters: Hyperthermia from the aspects of lipids and membranes. Int. J. Hyperth. 2013, 29, 491-499. [CrossRef]

17. Kang, Y.-S.; Ko, Y.-G.; Seoab, J.-S. Caveolin Internalization by Heat Shock or Hyperosmotic Shock. Exp. Cell Res. 2000, 255, 221-228. [CrossRef]

18. Zidovetzki, R.; Levitan, I. Use of cyclodextrins to manipulate plasma membrane cholesterol content: Evidence, misconceptions and control strategies. Biochim. et Biophys. Acta (BBA)-Biomembr. 2007, 1768, 1311-1324. [CrossRef]

19. Coutinho, A.; Silva, L.; Fedorov, A.; Prieto, M. Cholesterol and Ergosterol Influence Nystatin Surface Aggregation: Relation to Pore Formation. Biophys. J. 2004, 87, 3264-3276. [CrossRef]

20. Rothberg, K.G.; Heuser, J.E.; Donzell, W.C.; Ying, Y.-S.; Glenney, J.R.; Anderson, R.G. Caveolin, a protein component of caveolae membrane coats. Cell 1992, 68, 673-682. [CrossRef]

21. Sankaran, J.; Shi, X.; Ho, L.Y.; Stelzer, E.H.K.; Wohland, T. ImFCS: A software for imaging FCS data analysis and visualization. Opt. Express 2010, 18, 25468-25481. [CrossRef] [PubMed]

22. Ng, X.W.; Bag, N.; Wohland, T. Characterization of Lipid and Cell Membrane Organization by the Fluorescence Correlation Spectroscopy Diffusion Law. Chim. Int. J. Chem. 2015, 69, 112-119. [CrossRef] [PubMed]

23. Sankaran, J.; Bag, N.; Kraut, R.S.; Wohland, T. Accuracy and Precision in Camera-Based Fluorescence Correlation Spectroscopy Measurements. Anal. Chem. 2013, 85, 3948-3954. [CrossRef] [PubMed]

24. Péter, M.; Glatz, A.; Gudmann, P.; Gombos, I.; Török, Z.; Horváth, I.; Vigh, L.; Balogh, G. Metabolic crosstalk between membrane and storage lipids facilitates heat stress management in Schizosaccharomyces pombe. PLoS ONE 2017, 12, e0173739. [CrossRef] [PubMed]

25. Peksel, B.; Gombos, I.; Péter, M.; Vigh, L.; Tiszlavicz, Á.; Brameshuber, M.; Balogh, G.; Schütz, G.J.; Horváth, I.; Török, Z. Mild heat induces a distinct "eustress" response in Chinese Hamster Ovary cells but does not induce heat shock protein synthesis. Sci. Rep. 2017, 7, 15643. [CrossRef]

26. Chong, J.; Soufan, O.; Li, C.; Caraus, I.; Li, S.; Bourque, G.; Wishart, D.S.; Xia, J. MetaboAnalyst 4.0: Towards more transparent and integrative metabolomics analysis. Nucleic Acids Res. 2018, 46, W486-W494. [CrossRef]

27. Landry, J.; Chrétien, P.; Lambert, H.; Hickey, E.; Weber, L.A. Heat shock resistance conferred by expression of the human HSP27 gene in rodent cells. J. Cell Boil. 1989, 109, 7-15. [CrossRef]

28. Wang, H.-X.; Yang, Y.; Guo, H.; Hou, D.-D.; Zheng, S.; Hong, Y.-X.; Cai, Y.-F.; Huo, W.; Qi, R.-Q.; Zhang, L.; et al. HSPB1 deficiency sensitizes melanoma cells to hyperthermia induced cell death. Oncotarget 2016, 7, 67449-67462. [CrossRef]

29. Worley, B.; Powers, R. Multivariate Analysis in Metabolomics. Curr Metabolomics 2013, 1, 92-107.

30. Vígh, L.; Nakamoto, H.; Landry, J.; Harwood, J.L.; Horvath, I.; Gomez-Muñoz, A. Membrane Regulation of the Stress Response from Prokaryotic Models to Mammalian Cells. Ann. New York Acad. Sci. 2007, 1113, 40-51. [CrossRef]

31. Ciocca, D.R.; Cuello-Carrión, F.D.; Natoli, A.L.; Restall, C.; Anderson, R.L. Absence of caveolin-1 alters heat shock protein expression in spontaneous mammary tumors driven by Her-2/neu expression. Histochem. Cell Biol. 2012, 137, 187-194. [CrossRef] [PubMed]

32. Török, Z.; Crul, T.; Maresca, B.; Schütz, G.J.; Viana, F.; Dindia, L.; Piotto, S.; Brameshuber, M.; Balogh, G.; Péter, M.; et al. Plasma membranes as heat stress sensors: From lipid-controlled molecular switches to therapeutic applications. Biochim. et Biophys. Acta (BBA)-Biomembr. 2014, 1838, 1594-1618. [CrossRef] [PubMed]

33. Black, A.T.; Hayden, P.J.; Casillas, R.P.; Heck, D.E.; Gerecke, N.R.; Sinko, P.J.; Laskin, D.L.; Laskin, J.D. Regulation of Hsp27 and Hsp70 expression in human and mouse skin construct models by caveolae following exposure to the model sulfur mustard vesicant, 2-chloroethyl ethyl sulfide. Toxicol. Appl. Pharmacol. 2011, 253, 112-120. [CrossRef] [PubMed]

34. Kato, K.; Ito, H.; Kamei, K.; Iwamoto, I. Selective stimulation of Hsp27 and $\alpha$ B-crystallin but not Hsp70 expression by p38 MAP kinase activation. Cell Stress Chaperones 1999, 4, 94-101. [CrossRef]

35. Vitiello, M.; Finamore, E.; Raieta, K.; Kampanaraki, A.; Mignogna, E.; Galdiero, E.; Galdiero, M. Cellular cholesterol involvement in Src, PKC, and p38/JNK transduction pathways by porins. J. Interf. Cytokine Res. 2009, 29, 791-799. [CrossRef] 
36. Ladjohounlou, R.; Lozza, C.; Pichard, A.; Constanzo, J.; Karam, J.; Le Fur, P.; Deshayes, E.; Boudousq, V.; Paillas, S.; Busson, M.; et al. Drugs that modify cholesterol metabolism alter the p38/JNK-mediated targetedand nontargeted response to alpha and auger radioimmunotherapy. Clin. Cancer Res. 2019, 25, 4775-4790. [CrossRef]

37. Budzyński, M.A.; Puustinen, M.C.; Joutsen, J.; Sistonen, L. Uncoupling Stress-Inducible Phosphorylation of Heat Shock Factor 1 from Its Activation. Mol. Cell. Boil. 2015, 35, 2530-2540. [CrossRef]

38. Björk, J.K.; Sistonen, L. Regulation of the members of the mammalian heat shock factor family. FEBS J. 2010, 277, 4126-4139. [CrossRef]

39. Nefkens, I.; Negorev, D.G.; Ishov, A.; Michaelson, J.S.; Yeh, E.T.; Tanguay, R.M.; Müller, W.E.G.; Maul, G.G. Heat shock and $\mathrm{Cd} 2+$ exposure regulate PML and Daxx release from ND10 by independent mechanisms that modify the induction of heat-shock proteins 70 and 25 differently. J. Cell Sci. 2003, 116, 513-524. [CrossRef]

40. Boellmann, F.; Guettouche, T.; Guo, Y.; Fenna, M.; Mnayer, L.; Voellmy, R. DAXX interacts with heat shock factor 1 during stress activation and enhances its transcriptional activity. Proc. Natl. Acad. Sci. USA 2004, 101, 4100-4105. [CrossRef]

41. Sun, S.; Wen, J.; Qiu, F.; Yin, Y.; Xu, G.; Li, T.; Nie, J.; Xiong, G.; Zhang, C.; Liao, D.; et al. Identification of the C-terminal domain of Daxx acts as a potential regulator of intracellular cholesterol synthesis in HepG2 cells. Biochem. Biophys. Res. Commun. 2016, 480, 139-145. [CrossRef] [PubMed]

42. Oommen, D.; Giricz, Z.; Srinivas, U.K.; Samali, A. Atypical heat shock response and acquisition of thermotolerance in P388D1 cells. Biochem. Biophys. Res. Commun. 2013, 430, 236-240. [CrossRef] [PubMed]

43. Fisher, B.; Kraft, P.; Hahn, G.M.; Anderson, R.L. Thermotolerance in the absence of induced heat shock proteins in a murine lymphoma. Cancer Res. 1992, 52, 2854-2861. [PubMed]

44. Pinkwart, K.; Schneider, F.; Lukoseviciute, M.; Sauka-Spengler, T.; Lyman, E.; Eggeling, C.; Sezgin, E. Nanoscale dynamics of cholesterol in the cell membrane. J. Boil. Chem. 2019, 294, 12599-12609. [CrossRef]

45. Kern, R.; Joseleau-Petit, D.; Chattopadhyay, M.K.; Richarme, G. Chaperone-like Properties of Lysophospholipids. Biochem. Biophys. Res. Commun. 2001, 289, 1268-1274. [CrossRef]

46. Chasserot-Golaz, S.; Coorssen, J.R.; Meunier, F.A.; Vitale, N. Lipid Dynamics in Exocytosis. Cell. Mol. Neurobiol. 2010, 30, 1335-1342. [CrossRef]

47. Péter, M.; Balogh, G.; Gombos, I.; Liebisch, G.; Horvàth, I.; Török, Z.; Nagy, E.; Maslyanko, A.; Benkő, S.; Schmitz, G.; et al. Nutritional lipid supply can control the heat shock response of B16 melanoma cells in culture. Mol. Membr. Boil. 2012, 29, 274-289. [CrossRef]

48. Balogi, Z.; Multhoff, G.; Jensen, T.K.; Lloyd-Evans, E.; Yamashima, T.; Jäättelä, M.; Harwood, J.L.; Vígh, L.; Multhoff, G. Hsp70 interactions with membrane lipids regulate cellular functions in health and disease. Prog. Lipid Res. 2019, 74, 18-30. [CrossRef]

49. Poulcharidis, D.; Belfor, K.; Kros, A.; Van Kasteren, S.I. A flow cytometry assay to quantify intercellular exchange of membrane components. Chem. Sci. 2017, 8, 5585-5590. [CrossRef] 